Preprint version_Citation:

Mihai FC., Banica A., Grozavu., A., 2019. Backyard burning of household waste in rural areas. Environmental impact with focus on air pollution. 19th International Multidisciplinary Scientific GeoConference on Ecology, Economics, Education and Legislation SGEM 2019, Conference Proceedings, vol.19, Issue 5.1 pp. 55-62

\title{
BACKYARD BURNING OF HOUSEHOLD WASTE IN RURAL AREAS. ENVIRONMENTAL IMPACT FOCUSING ON AIR POLLUTION
}

\author{
CS III Dr. Florin-Constantin Mihai ${ }^{{ }^{*}}$ Lect. Dr., CS III Alexandru Banica ${ }^{2,3}$ \\ Prof. Dr. Adrian Grozavu ${ }^{2}$ \\ ${ }^{1}$ Department of Research, Faculty of Geography and Geology, Alexandru Ioan Cuza University \\ of Iasi, Romania, Corresponding author: mihai.florinconstantin@gmail.com \\ 2 Department of Geography, Faculty of Geography and Geology, Alexandru Ioan Cuza \\ University of Iasi, Romania ${ }^{3}$ Romanian Academy, Iasi Branch, Geography Group, Romania
}

\begin{abstract}
The paper examines the environmental threats associated with the burning of household waste in open piles across rural communities with a focus on Neamt County (Romania) as a case study of uncontrolled waste disposal practice. This option derived from the lack of efficient municipal waste collection schemes, and on the other hand, it is a traditional disposal route for agricultural wastes besides open dumping on the surroundings. This study estimates the potential amounts of household waste uncollected by formal waste management services to be burnt by rural communities related to regional waste management features and how such bad practice interacts with geographical conditions. The paper performs a quantitative analysis of waste indicators and makes estimations on consequent environmental impact focusing on inventorying air pollutants. The spatial analysis provides an appropriate cartographic representation of the analyzed phenomenon. The conclusions converge towards two main ideas: 1) open burning of mixed household waste could be a significant air pollution source at the local scale, and 2) better rural waste management practices are needed to be implemented in the study area to mitigate environmental and public health threats.
\end{abstract}

Keywords: waste management, open burning, rural areas, air pollution

\section{INTRODUCTION}

Rural areas are prone to uncontrolled waste disposal practices across the globe due to the lack of sound waste collection schemes [1]. The amounts of waste generated by rural communities are frequently managed at the household level through open burning practices or open dumping on surroundings [2]. In Eastern Europe, rural communities struggle to provide reliable waste management services under the EU legislative framework. Rural population coverage for such services is emerging in later years in Romania, but open burning and illegal dumping of waste still prevail across the villages. 
This paper examines one of the main routes for household waste uncollected via backyard burning practices in Neamt county, part of North-East development region.

\section{MATERIALS AND METHODS}

Neamt County comprises four urban areas (Piatra Neamt - county capital, Roman city, Targu Neamt, Bicaz and Roznov towns), but, according to the last population census (2011), most of the population lives in rural areas (301167 inhabitants). There are 78 rural municipalities (communes) which include 347 villages in their administrative area. In this context, rural waste management issues must be a key environmental concern at the county level. This study analyses the open burning practices in 2012 when rural population was partially covered by waste collection services (WCS) and 2015 when all communes of Neamt County were served by waste operators, but with gaps in the waste collection schemes. Therefore, the main two sources of household waste uncollected emerge such as (i) household waste generated by rural inhabitants without access to WCS in 2012; (ii) household waste uncollected due to an inefficient waste collection system (2012 and 2015). These sources feed open burning practices in rural areas besides agricultural wastes. The paper aims to estimate the potential amounts of household waste burnt in open piles by rural communities. First, the amounts of household waste uncollected must be determined using the following equation:

$$
\mathrm{Q}_{\text {hwu }}\left(\mathrm{t} . \mathrm{yr}^{-1}\right)=\mathrm{P}_{\text {nowCs }} \times \text { Grw x 365/1000, where: }
$$

$\mathrm{Q}_{\text {hwu }}$ - the amount of household waste generated and uncollected by waste operators $\left(\right.$ t.yr. $\left.{ }^{-1}\right)$

$\mathrm{P}_{\text {nowCS }}=$ number of inhabitants with no access to WCS

$\mathrm{Grw}=$ per-capita waste generation rate in rural areas $\left(\mathrm{kg}\right.$. inhab.day $\left.{ }^{-1}\right)$

Regional per-capita waste generation rates such of $0.31 \mathrm{~kg}$.inhab.day ${ }^{-1}$ are used for rural areas based on field experiments [3] which are below than flat national rate of 0.4 kg.inhab.day ${ }^{-1}$ stipulated in environmental reports [4].

Collection efficiency must be determined to calculate the household waste uncollected from rural municipalities served by waste operators. The last local environmental report pointed out that collection rate average between $2010-2015\left(0.18 \mathrm{~kg}\right.$. kg.inhab.day $\left.{ }^{-1}\right)$ is much below regional per-capita generation rate of $0.31 \mathrm{~kg}^{\text {inhab.day }}{ }^{-1}$ [5].

This parameter is calculated as the ratio of the collection rate performed by waste operators from regional waste generation rate resulting in a value of $58 \%$. The collection efficiency of $60 \%$ (WCS60) is further considered in the following equation:

$$
\mathrm{Q}_{\text {hwut }}=\left(\mathrm{Q}_{\mathrm{hwps}}-\mathrm{Q}_{\mathrm{hwps}} \times \mathrm{0} \text { 0.6) }+\mathrm{Q}_{\mathrm{hwu}}\right.
$$

$\mathrm{Q}_{\text {hwut }}=$ total amounts of household waste uncollected by formal WCS

$\mathrm{Q}_{\mathrm{hwp}}=$ amounts of household waste generated by population with access to WCS using the same per-capita generation rate $\left(0.31 \mathrm{~kg}\right.$.inhab.day $\left.{ }^{-1}\right)$.

The total amounts of household uncollected by WCS are calculated at the commune level. The next step is to determine the potential amounts of household waste burnt $\left(\mathrm{Q}_{\mathrm{hwb}}\right)$ using the following equation:

$$
\mathrm{Q}_{\text {hwb }}=\mathrm{Q}_{\text {hwut }} * \mathrm{C}_{\mathrm{hwf}} * \mathrm{~B}_{\mathrm{hwf}}
$$

$\mathrm{Q}_{\mathrm{hwb}}=$ amounts of household waste openly burnt

$\mathrm{Q}_{\text {hwut }}=$ total amounts of household waste uncollected by formal WCS

$\mathrm{C}_{\text {hwf }}=$ combustible household waste fraction

$\mathrm{B}_{\mathrm{hwf}}=$ fraction of household waste that actually is burnt in the open pile 
Combustible household waste fraction derived from municipal waste characterization, specifically to rural areas provided by the regional waste management plan in NorthEast region based on waste operators' estimations [6]. The combustible waste fractions considered are the biowaste (62\%), paper and cardboard (9\%), textile (3\%) and plastics $(6.5 \%)$ excluding metals, glass, and undefined fractions. Such fraction counts to $80.5 \%$ so the $\mathrm{C}_{\mathrm{hwf}}$ is 0.8 . Wood fraction is missing from waste characterization (0\%) as reused as heating/cooking fuel in rural households. The fraction of household waste that actually is in an open pile is 0.6 as default value suggested by Kumari et al. [7].

The potential amounts of household waste burnt are calculated for each commune and thematic cartography reveals the geographical disparities within the study area. The estimation of emissions was made taking into account the main atmospheric pollutants that result from waste burning. The annual emission of the selected compounds $\left(\mathrm{E}_{\mathrm{i}}\right)$ for each commune from Neamt County is calculated as the product of the amount of waste burned and an emission factor:

$$
\mathrm{E}_{\mathrm{i}}=\mathrm{Q}_{\mathrm{hwb}} \times \mathrm{EF}_{\mathrm{i}}
$$

where $\mathrm{Q}_{\mathrm{hwb}}$ is the total amount of waste burned and $\mathrm{EF}_{\mathrm{i}}$ is the emission factor or mass of a specific compound emitted per mass of waste burned ( $\mathrm{g} \mathrm{kg}^{-1}$ waste burned). The emission factors for the selected pollutants were established by taking as reference various estimates from the last 15 years.

Table 1. Emission factors for pollutants considered in this study

\begin{tabular}{|c|c|c|}
\hline \multirow{2}{*}{ Pollutants } & Emission factors & \multirow{2}{*}{ Sources } \\
\hline & $\mathrm{g} \mathrm{kg}^{-1}$ waste & \\
\hline $\mathrm{CO} 2$ & 1453 & \multirow{13}{*}{$\begin{array}{l}\text { Akagi et al. [8] } \\
\text { Chen et al. [9] } \\
\text { Lemieux et al. [10] } \\
\text { Wiedinmyer et al. [2] } \\
\text { Woodall et al. [11] }\end{array}$} \\
\hline $\mathrm{CO}$ & 38 & \\
\hline $\mathrm{CH}_{4}$ & 3.7 & \\
\hline ethylene $\left(\mathrm{C}_{2} \mathrm{H}_{4}\right)$ & 1.26 & \\
\hline benzene $\left(\mathrm{C}_{6} \mathrm{H}_{6}\right)$ & 0.9 & \\
\hline $\begin{array}{l}\text { total polyciclic aromatic } \\
\text { hydrocarbons (PAHs) }\end{array}$ & 0.3 & \\
\hline ammonia $\left(\mathrm{NH}_{3}\right)$ & 1.12 & \\
\hline sulfur dioxide $\left(\mathrm{SO}_{2}\right)$ & 0.5 & \\
\hline $\begin{array}{c}\text { nitrogen oxides (NOx as } \\
\text { NO) }\end{array}$ & 3.74 & \\
\hline $\mathrm{PM}_{2.5}$ & 9.8 & \\
\hline $\mathrm{PM}_{10}$ & 11.9 & \\
\hline $\begin{array}{l}\text { particulate black carbon } \\
\text { (BC) }\end{array}$ & 0.65 & \\
\hline $\begin{array}{c}\text { Mercury }(\mathrm{Hg}) \\
\text { polychlorinated } \\
\text { biphenyls (PCBs) }\end{array}$ & $\begin{array}{l}0.00021 \\
0.00031\end{array}$ & \\
\hline
\end{tabular}

\section{RESULTS AND DISCUSSION}

Figure 1 reveals the geographical distribution of household waste estimated to be burnt by rural households within the study area for 2012 and 2015 . 


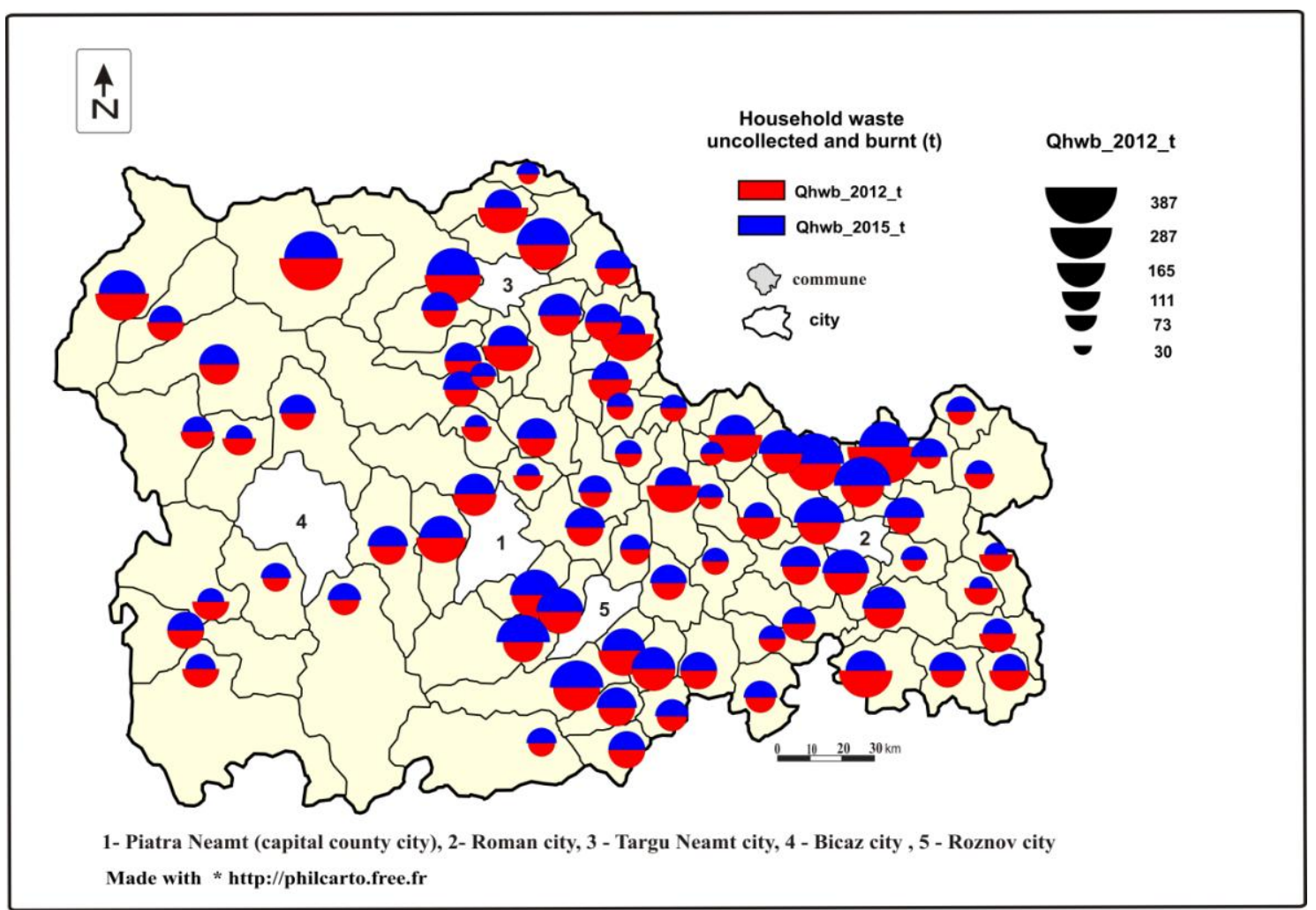

Figure 1. Estimation of household waste burnt in rural areas of Neamt County

These values range from 64 to 553 tons for both years, where Eastern and Southeastern rural communities are more prone to open burning practices mainly in hilly regions beside the wild dumps scattered on the surroundings. In mountain and subcarpathian areas (western half of the county) waste dumping on watercourses compete with backyard burning option as uncontrolled waste disposal practices.

The backyard burning practice could be at a significant level across well-populated rural areas downstream to Piatra-Neamt city or in the proximity of Targu-Neamt town.

Distant villages from urban areas are more likely to be ignored by waste operators and a low collection frequency leads to larger amounts of waste to be managed at household level via backyard burning or their improper disposal on wild dumps despite breaking the law [12]. Poorer and marginalized communities are more prone to backyard burning practices instead to pay the sanitation fees if these are not covered by the local council budget. Peripheral areas of the southeast county (Icusesti, Poienari, Pancesti) have not been connected to WCS in 2012 as same as Doljesti commune located in the Siret corridor valley. In such localities, wild dumps and backyard burning are the main disposal options for household waste uncollected as for Bargoaoani, Dulcesti (central hilly regions) or Pastraveni commune (the Eastern border of the county).

In 2012, these seven communes without access to WCS contributed with $3088.74 \mathrm{t}$ household waste burnt of totally $8273.62 \mathrm{t}$. The amounts of potential household waste burnt are lower in 2012, because of the expansion of waste collection coverage towards all communes of the Neamt County.

However, the total amount of household waste burnt by rural households is still significant $\left(7628.38 \mathrm{t} \mathrm{year}^{-1}\right)$ due to the gaps in the waste collection systems $(60 \%)$ revealed by the poor collection rates compared to the regional rural waste generation 
rate. Table 2 shows an estimation of the pollution levels resulted from the burning of household waste across all rural communities of Neamt County based on emission factors. At the local level, such disposal method could be an important source of particulate matter pollution, black carbon, benzene or PAHs which pose further risks to human health.

Table 2. Pollution emissions associated with rural backyard burning practices

\begin{tabular}{|r|c|c|c|c|c|c|}
\hline kg/year & $\mathrm{BC}$ & $\mathrm{PM}_{10}$ & $\mathrm{PM}_{2.5}$ & $\mathrm{PAHs}$ & $\mathrm{NOx}$ & $\mathrm{SO}_{2}$ \\
\hline 2012 & 5377.85 & 98456.10 & 81081.50 & 2482.09 & 30943.35 & 4136.81 \\
\hline 2015 & 2581.37 & 47258.93 & 38919.12 & 1191.40 & 14852.81 & 1985.67 \\
\hline kg/year & $\begin{array}{c}\text { Ethylene } \\
\left(\mathrm{C}_{2} \mathrm{H}_{4}\right)\end{array}$ & $\begin{array}{c}\text { benzene } \\
\left(\mathrm{C}_{6} \mathrm{H}_{6}\right)\end{array}$ & $\mathrm{NH}_{3}$ & $\mathrm{CO}_{2}$ & $\mathrm{CO}$ & $\mathrm{CH}_{4}$ \\
\hline 2012 & 10424.76 & 7446.26 & 9266.46 & 12021573 & 314397.64 & 30612.40 \\
\hline 2015 & 5003.89 & 3574.20 & 4447.90 & 5770355 & 150910.87 & 14693.95 \\
\hline
\end{tabular}

Other hazardous substances like mercury $(2.57 \mathrm{~kg})$ or PCBs $(1.59 \mathrm{~kg})$ are estimated to be much less emitted for both years. However, the presence of hazardous items (such as e-waste components, batteries, spray, contaminated plastics, colored papers) in the open piles can increase the pollution levels of in-situ scale and fire risks on the surroundings. The paper estimates that rural communities burnt $12244.96 \mathrm{t}$ household waste of which $795.92 \mathrm{t}$ plastics in both years (2012 and 2015). This fraction poses serious threats to the living organism releasing dioxins and furans and other toxic substances into the atmosphere in case of incomplete combustion. Backyard burning activities contribute to greenhouse gases via $\mathrm{CO}_{2}$ and $\mathrm{CH}_{4}$, which are not taken into consideration for the regional inventory reporting system. Also, these open-fire activities are an additional pollution source to $\mathrm{SO}_{2}, \mathrm{NO}_{\mathrm{x}}, \mathrm{CO}$, and $\mathrm{NH}_{3}$. All estimated pollution emissions into the air have lower levels in 2015 because of the expansion of waste collection services towards all rural municipalities.

However, the gaps in waste collection schemes still enable open burning practices in rural areas contributing to air pollution as suggested by Table 2. Table 3 reveals the emissions from those rural municipalities without sanitation services which were prone to massive open burning practices in 2012. The incomplete combustion process of mixed wastes release harmful pollutants into the environment and the local population is exposed to inhale such toxic substances. Demographic features of each rural municipality influence the potential magnitude of air pollution. Despite the pollution levels that seems to pale compared to major industrial facilities from urban areas, these diffuse pollution sources should not be ignored at the local scale where environmental damage could be significant. 
Table 3. Open burning pollution caused by rural population without WCS in 2012

\begin{tabular}{|l|c|c|c|c|c|}
\hline $\begin{array}{l}\text { Commune / } \\
\text { kg year }^{-1}\end{array}$ & BC & PM2.5 & PM10 & PAHs & $\begin{array}{c}\text { Benzene } \\
\left(\mathrm{C}_{6} \mathrm{H}_{6}\right)\end{array}$ \\
\hline Bargauani & 121.34 & 1829.37 & 2221.38 & 56.00 & 168.00 \\
\hline Doljesti & 251.25 & 3788.08 & 4599.81 & 115.96 & 347.88 \\
\hline Dulcesti & 78.76 & 1187.47 & 1441.92 & 36.35 & 109.05 \\
\hline Icusesti & 132.88 & 2003.42 & 2432.72 & 61.33 & 183.99 \\
\hline Pancesti & 47.20 & 711.63 & 864.12 & 21.78 & 65.35 \\
\hline Pastraveni & 124.05 & 1870.35 & 2271.14 & 57.26 & 171.77 \\
\hline Poienari & 51.01 & 769.11 & 933.92 & 23.54 & 70.63 \\
\hline $\begin{array}{l}\text { Rural pop_no } \\
\text { WCS_total_county }\end{array}$ & 2007.69 & 30269.73 & 36756.10 & 926.62 & 2779.87 \\
\hline
\end{tabular}

Thus, air pollution studies associated with backyard burning practices across rural communities should be further performed in Romania including experimental measures on the field. Full coverage of the rural population to formal waste management services is imperative to reduce air pollution issues resulting from such open burning activities. In fact, the backyard burning practices and other open fire activities are forbidden by the law. The burning of vegetal remains, garbage, waste and other combustible materials without obtaining a fire permit and without taking measures to prevent the fire from spreading to neighbors, is a contravention according to art. 1, par. 3 of G.D no. $537 / 2007$ and shall be sanctioned by a fine from 1,000 to 2,500 lei (1 EUR -4.75 lei). A special permit is required from the local rural council in order to further proceed with controlled open-air burning practices under certain conditions as recommended by the Inspectorate for Emergency Situations [13]:

- The use of open fire is not allowed at distances of less than $40 \mathrm{~m}$ from places with explosion hazard (combustible gases and liquids, flammable vapors, explosives, etc.) and $10 \mathrm{~m}$ of combustible materials or substances (wood, paper, asphalt, bitumen, oil, etc.) without being supervised and ensured by adequate measurement.

- No wind or prolonged drought as meteorological conditions

- Special sites with reduced fire risks for open fire operations must be nominated by local councils;

- Open-air activities must be performed only in daylight;

- Collecting biowastes (agricultural waste, garden waste, kitchen waste) in dry piles and in quantities that allows the burning process to be safely controlled;

- Cleaning the vegetation around each pile over a distance of $5 \mathrm{~m}$;

- Permanent supervision of the open burning activity;

- Providing means and devices to extinguish any fires;

- Total extinction of the fire before leaving the place burning

- Burning sites must prevent the fire from spreading to the forest or built-up areas; do not affect the electrical and communications networks, gas or oil pipelines, other combustible materials 
The burning of agricultural wastes is still quite widespread practice on the fields or near the households mainly in spring and autumn seasons. Uncontrolled open-fire activities including the burning of wastes (agricultural or household as the source of origin) lead to spontaneous fires. As an example, on 19 April 2018, two fire incidents happened due to improper open burning practices in rural areas requiring fire crew assistance. In Vanatori Neamt commune, almost 2 tons of household waste burnt (which required the intervention of 1 fire truck from Targu Neamt city division), while in Trifesti commune 5 tons of household and agricultural wastes burnt (requiring the intervention of 2 fire trucks from the Roman city). Both events were announced around 5 PM according to the Neamt Inspectorate for Emergency Situations [14].

Local council's decisions provide the legal framework for open fire activities in each commune. A person is nominated to be responsible for legal supervision with the aid of Voluntary Service for Emergency Situations. Rural councils should establish special sites for such open fire activities. As an example, Pancesti commune identified four sites to serve each village under administration.

\section{CONCLUSION}

The paper estimates that rural communities burnt 12244.96 t household waste in both years (2012 and 2015) of which $8273.62 \mathrm{t}$ derived from rural inhabitants not covered by waste operators in 2012 (including seven communes without any waste collection services in their administrative area). The paper examines the air pollution issues associated with backyard burning practices based on emission factors for 14 pollutants. The primary concern is the amount of hazardous emissions released into the air such as black carbon, $\mathrm{PM}_{2.5}, \mathrm{PM}_{10}$, PAHs or benzene due to the low temperature and incomplete combustion of mixed wastes increasing the public health threats and environmental damage risk at the local scale. Open burning of household waste constitutes an additional pollution source for $\mathrm{NO}_{\mathrm{x}}, \mathrm{SO}_{2}, \mathrm{CO}$ or greenhouse gases $\left(\mathrm{CO}_{2}, \mathrm{CH}_{4}\right)$ which are not considered in the local and national reports. The improvement of collection efficiency across the most populated communes is imperative to reduce the negative impact of backyard burning practices across the county in the short term supported by the better implementation of waste collection schemes through the new regional integrated waste management system. There is a serious knowledge gap concerning air pollution sources in rural areas of Romania, where backyard burning could play a key role due to the poor waste management infrastructure. Such studies should be further performed in other regions supported by experimental analysis (where possible) to better understand the pollution mechanisms and to adjust the emission factors to regional features.

\section{ACKNOWLEDGEMENTS}

This work was supported by a grant of the "Alexandru Ioan Cuza" University of Iasi, within the Research Grants program, Grant UAIC, code GI-UAIC-2017-06. 


\section{REFERENCES}

[1] Hoornweg, D., Bhada-Tata, P. What a waste: a global review of solid waste management. Urban Development Series Knowledge Papers, World Bank, Washington D.C. 2012

[2] Wiedinmyer, C., Yokelson, R. J., \& Gullett, B. K. Global Emissions of Trace Gases, Particulate Matter, and Hazardous Air Pollutants from Open Burning of Domestic Environmental Science \& Technology, 48(16), 9523-9530, 2014, https://doi.org/10.1021/es502250z

[3] Ciuta S., Apostol T., and Rusu V., Urban and Rural MSW Stream Characterization for Separate Collection Improvement, Sustainability, 7, 916-931, 2015, doi:10.3390/su7010916

[4] National Environmental Protection Agency 2018. An environmental status report in Romania 2017 (in Romanian)

[5] Environmental Protection Agency of Neamt county 2018. An environmental status report in Neamt county in 2017 (in Romanian)

[6] Regional Environmental Protection Agency of Bacau 2006. Regional waste management plan of North East Region [in Romanian]

[7] Kumari K, Kumar S, Vineel R., Khare A., Kumar R., Emission from Open Burning of Municipal Solid Waste in India, Environmental Technology, 2017, doi:

10.1080/09593330.2017.1351489

[8] Akagi, S. K., Yokelson, R. J., Wiedinmyer, C., Alvarado, M. J., Reid, J. et al.,. Emission factors for open and domestic biomass burning for use in atmospheric models. Atmospheric Chemistry and Physics, 11(9), 4039-4072, 2011, https://doi.org/10.5194/acp-11-4039-2011

[9] Lemieux, P. M.; Lutes, C. C.; Santoianni, D. A. Emissions of organic air toxics from open burning: A comprehensive review. Prog. Energy Combust. Sci. 2004, 30 (1), $1-32$.

[10] Chen, L. G.; Liu, M.; Fan, R. F.; Ma, S. X.; Xu, Z. C.; Ren, M. Z.; He, Q. S. Mercury speciation and emission from municipal solid waste incinerators in the Pearl River Delta, South China. Sci. Total Environ., 447, 396-402, 2013

[11] Woodall, B. D.; Yamamoto, D. P.; Gullett, B. K.; Touati, A. Emissions from smallscale burns of simulated deployed u.s. military waste. Environ. Sci. Technol., 46 (20), 10997-11003, 2012

[12] Mihai FC. Waste collection in rural communities: challenges under EU regulations. A case study of Neamt County, Romania. J Material Cycles Waste Manage, 20 (2):1337-1347 , 2018, doi: 10.1007/s10163-017-0637-x

[13] Inspectorate for Emergency Situation Dambovita. Rules for open-air fire activities https://www.isudb.ro/informare_preventiva/pliante/reguli_foc_deschis.pdf (Accessed on 10 March 2019)

[14] Inspectorate for Emergency Situation Neamt County https://www1 agerpres.ro/comunicate/2018/04/20/comunicat-de-presa-isu-neamt-12-3955 Accessed on 10 March 2019) 